\title{
Qualitative study of the implementation of the Continuity of Care and Rehabilitation Program for people with severe mental disorders in Peru*
}

\author{
Francisco Diez-Canseco, ${ }^{1}$ Jefferson Rojas-Vargas, ${ }^{1}$ Mauricio Toyama, ${ }^{1}$ María Mendoza, ${ }^{2}$ Victoria \\ Cavero, ${ }^{1}$ Humberto Maldonado, ${ }^{2}$ July Caballero, ${ }^{2}$ and Yuri Cutipé ${ }^{2}$
}

Suggested citation Diez-Canseco F, Rojas-Vargas J, Toyama M, Mendoza M, Cavero V, Maldonado H, et al. Qualitative study of the implementation of the Continuity of Care and Rehabilitation Program for people with severe mental disorders in Peru. Rev Panam Salud Publica. 2020;44:e169. https://doi.org/10.26633/RPSP.2020.169

ABSTRACT

Objective. Describe the implementation of the Continuity of Care and Rehabilitation Program (PCC-R) in community mental health centers (CSMCs, Spanish acronym) in Peru.

Methods. Qualitative study of the implementation of the PCC-R in four CSMCs in Lima and La Libertad, Peru. Forty-two individual semi-structured interviews were conducted, as well as a focus group with five participants, for a total of 47 informants, including users, family members, and professionals involved in the design, implementation, and monitoring of the program.

Results. The PCC-R is a key program for community mental health services in Peru and it enjoys broad acceptability. Providers and users report satisfaction with its results; however, the program lacks a policy document specifying its objectives, organization, and activities. This would explain the variability in its implementation. The PCC-R has limitations in terms of management of financial and human resources, and it is necessary to improve training and supervision. There is consensus on the need, usefulness, and viability of developing a system to monitor the PCC-R. Good practices and suggestions are presented with a view to addressing these challenges. Conclusions. The PCC-R is a flagship program for the CSMCs and for mental health reform in Peru. It has achieved broad acceptability among providers and users. Its implementation combines successes and difficulties, with pending tasks that include developing a policy document, improving resource management, strengthening training and supervision, and implementing a monitoring system for continuous improvement of the program.

Keywords $\quad$ Continuity of patient care; mental health; community mental health centers; qualitative research; Peru.

Neuropsychiatric disorders affect one out of four Peruvians $(1,2)$ and are the leading cause of the country's disease burden $(12.7 \%$ ) (3). However, between $75 \%$ and $85 \%$ of those who need mental health care do not receive it $(1,2)$. To bridge this gap, Peru instituted a mental health reform $(4,5)$. Law 29889 was passed in 2012 to guarantee the provision of mental health

\footnotetext{
* Official English translation from the original Spanish manuscript made by the Pan American Health Organization. In case of discrepancy, the original version shall prevail. Access to original manuscript: https://doi.org/110.26633 /RPSP.2020.134
}

services, and a budget program was established in 2014 to cover these services $(6,7)$. The reform, headed by the Mental Health Department (DSAME) of Peru's Ministry of Health (MINSA), promotes a community care model (Figure 1), that features the creation of community mental health centers (CSMCs) designed to serve people with complex mental health problems. There are 
FIGURE 1. Peru's community health care model and the PCC-R

\begin{tabular}{|c|c|c|c|}
\hline $\begin{array}{l}\text { Support the promotio } \\
\text { problems and/or mental } \\
\text { being created in which }\end{array}$ & $\begin{array}{l}\text { ction of mental health and } \\
n \text { their community. To achie } \\
\text { mental health centers (CSM } \\
\text { Program (PCC-R) are funda }\end{array}$ & $\begin{array}{l}\text { y of care for people v } \\
\text { a new mental health } \\
\text { the Continuity of Car } \\
\text { arts. }\end{array}$ & $\begin{array}{l}\text { losocial } \\
\text { network is } \\
\text { labilitation }\end{array}$ \\
\hline $\begin{array}{l}\text { The purpose of the PCC-R is for } \\
\text { users to achieve: } \\
\text { a. Their maximum level of }\end{array}$ & $\begin{array}{l}\text { Continuity of Care and } \\
\text { Rehabilitation Program } \\
\text { (PCC-R) }\end{array}$ & & $\begin{array}{l}\text { Hospitals and } \\
\text { health centers }\end{array}$ \\
\hline $\begin{array}{l}\text { autonomy. } \\
\text { b. Their maximum functional } \\
\text { recovery. }\end{array}$ & & $\begin{array}{l}\text { Community mental } \\
\text { health centers } \\
\text { (CSMCs) }\end{array}$ & \\
\hline $\begin{array}{l}\text { c. Social integration in their family, } \\
\text { community, and work } \\
\text { environment. } \\
\text { d. Exercise their citizenship. }\end{array}$ & $\begin{array}{l}\text { Job and psychosocial } \\
\text { rehabilitation centers }\end{array}$ & & $\begin{array}{l}\text { Protected homes } \\
\text { and residences }\end{array}$ \\
\hline
\end{tabular}

Source: Produced by authors based on references 6 and 9 .

currently 155 CSMCs throughout Peru, with 281 expected by $2021(8)$.

A key program in the CSMCs is the Continuity of Care and Rehabilitation Program (PCC-R), which is specifically designed for people with severe mental disorders (SMDs) whose disability and psychosocial dependency requires frequent and prolonged care $(9,10)$. International evidence demonstrates the effectiveness of these programs in people with SMDs, which result in improved social functioning, adhesion to and satisfaction with treatment, and reduced severity of symptoms and hospitalization times $(11,12)$.

In Peru, a case manager monitors every user of the PCC-R. This manager is in charge of supporting them and ensuring their timely care, within and outside of the CSMCs, as part of an individualized continuity of care plan (ICCP) (9).

In the reform's early years, activity focused on ensuring the creation and sustainability of the CSMCs where the PCC-R was to be implemented, based on general guidelines set out in the CSMC policy document (9). Considering the time that has passed and the number of CSMCs, there is a need to know how the PCC-R has been working and identify lessons for improving it.

The purpose of this study, which was conducted by the DSAME and CRONICAS, the Center of Excellence in Chronic Diseases at the Universidad Peruana Cayetano Heredia $(\mathrm{UPCH})$, was to describe the implementation of the PCC-R, its organization, and principal activities, and to evaluate its acceptability and adoption, and obtain suggestions for improvement.

\section{MATERIALS AND METHODS}

To achieve our objective, we conducted a qualitative study to describe the current state of the PCC-R based on the perceptions and experiences of the key participants involved in it (13).

The study is part of the Improving Program Implementation through Embedded Research (iPIER) initiative developed by the Alliance for Health Policies and Systems Research in collaboration with the Pan American Health Organization (PAHO). This initiative places program implementers in research centers in order to understand the flaws in health systems that create obstacles to implementation, facilitating the identification of solutions and contributing to the effectiveness of health programs and policies (14).

The study was conducted in four CSMCs-two in Lima, the capital of Peru, and two in La Libertad on the northern coastselected because they have the most experience in implementing the PCC-R. In each region, plans were made to invite six case managers (for a total of 12), two statisticians from each CSMC (total of four), eight users (total of 16), four family members (total of eight) and one or two local mental health professionals. Six officials from the central Ministry of Health, five from the DSAME and one from the General Information Technology Office (OGTI) were also invited, for a total of 47 or 48 informants.

Convenience sampling was used to select the participants (15). The inclusion criteria were: adults who had signed an informed consent, had been in the PCC-R program at least six months (users and family members); and the managers who had worked the longest with the PCC-R in each CSMC.

As for qualitative techniques, focus groups were used for policy makers from the DSAME and semi-structured interviews were used for the others. A focus group guide and six interview guides were designed, one for each profile: managers, statisticians, users, family members, local officials, and the OGTI official. A file was used to collect sociodemographic data: sex, age, occupation, and length of time in the PCC-R.

Before collecting data, the study was presented in Lima and La Libertad. DSAME decisionmakers assisted in the selection of local officials and case managers, and these managers assisted in the selection of users and family members. After the selections were made, the inclusion criteria were confirmed and informed consents were obtained. The interviews and focus group were conducted and analyzed by the CRONICAS team and were recorded with the participants' consent.

The audio recordings were transcribed and coded using the ATLAS.ti 7.5 software. The content was analyzed in order to organize and categorize the collected data for subsequent interpretation and to draw substantive conclusions (16). Adoption and acceptability of the PCC-R were defined, respectively, as: i) the intention, initial decision, or action to implement the 
program activities; and ii) the perception of those involved as to whether the program was pleasant or satisfactory (17). For each informant profile, a code book was created with descriptive categories to organize the findings. The initial codes were designed based on the interview topics in the guides, and any new topics that emerged during coding were added. Coding was standardized by the investigators and the perspectives expressed in the different profiles were triangulated.

The study was approved by the Institutional Ethics Committee of the UPCH and PAHO's Ethics Review Committee (PAHOERC). All informants voluntarily participated after signing an informed consent form and their names were replaced by codes to protect their identity. Any information that would facilitate their identification was omitted.

\section{RESULTS}

Forty-two (42) interviews and a focus group were conducted with a total of 47 participants (Table 1). The decisionmakers and managers stated the PCC-R combines elements of different models, such as "case management" (18) and "assertive community treatment" (19), and includes tools adapted from other local health programs.

Although it has been used since 2016, the PCC-R does not have a specific policy document that describes in detail its objectives, organization, activities, and monitoring. Instead, there is a recommendation with general guidelines that is shared with new CSMCs, which were gradually adapted for their specific context and resources. Four CSMCs were already using the PCC-R with a common general vision, but with important differences. Some of the identified similarities were: i) the PCC-R is intended for people with SMDs,; ii) it offers care that is comprehensive, ongoing, and close to those who need it; iii) it seeks to recover lost abilities; and iv) it is coordinated with the intramural and extramural services of the CSMC. The decisionmakers and managers stressed the need to have technical documents for the PCC-R that would guide the work of health personnel but that would still be flexible and consider the diversity of sociocultural contexts and resources.

The CSMCs have an interdisciplinary team of professionals involved in the PCC-R (psychiatrist, psychologist, and occupational therapist, among others), although it is usually nurses who assume the role of managers and coordinators.
The coordinator organizes and supervises the operation of the PCC-R. Each manager is assigned between three and six users in order to design an ICCP tailored to their needs. Together with the other CSMC professionals, the manager must perform, coordinate, and monitor the completion of ICCP activities.

PCC-R activities are similar in all CSMCs, but vary in quantity and frequency, depending on the severity of the condition and needs of each user (Table 2). All of the CSMCs classify severity using the "traffic light" system: red (high), yellow (medium) and green (low).

The training of health workers involved in the PCC-R has varied greatly, in terms of methodology, quality, and duration. Some professionals completed internships abroad which lasted up to six months, where they observed how the PCC-R was implemented and took virtual courses. Most of the managers received training under the cascade model (20), in replications lasting one to three days and carried out by the coordinators. The Ministry of Health reviewed the training materials. The majority of the managers received a single training session; enhancement or refresher sessions were not the norm. For the decision makers, variability in their training would partially explain the differences in how the PCC-R is implemented in the different CSMCs.

The managers' opinions on training was generally positive, although the majority mentioned the need for more intensive and practical training, offered by professionals who have used the PCC-R.

Furthermore, professionals in Lima said that they did not receive support in the program, while those in La Libertad said that they received general supervision of their work in the CSMC and that, with regard to the PCC-R, it was limited to reviewing the documentation. The decisionmakers added that the PCC-R did not have a policy document for these activities.

Although there is no standard procedure for admitting users to the PCC-R, the informants agree that it is intended for people with SMDs and describe similar admittance processes. PCC-R candidates are identified during the "welcome" to the CSMC session (entry evaluation) or when a treatment does not produce results. Admittance decisions and classification of the level of severity (red, yellow, or green) tend to be based on clinical and psychosocial assessments that the professionals share at meetings; scales are not commonly used. After deciding to accept a user, the PCC-R coordinator assigns him or her to a

TABLE 1. Participants by region, type of informant, duration, and technique used

\begin{tabular}{|c|c|c|c|c|c|c|c|c|c|}
\hline \multirow{2}{*}{$\begin{array}{l}\text { Data collection } \\
\text { technique }\end{array}$} & \multirow[t]{2}{*}{ Informants } & \multirow{2}{*}{$\begin{array}{l}\text { Duration } \\
\text { (minutes) }\end{array}$} & \multicolumn{2}{|c|}{ National } & \multicolumn{2}{|c|}{ Lima } & \multicolumn{2}{|c|}{ La Libertad } & \multirow[t]{2}{*}{ Total } \\
\hline & & & $\mathrm{M}$ & W & M & W & $\mathrm{M}$ & W & \\
\hline Focus group & Policy makers of the DSAME & 199 & 1 & 4 & & & & & 5 \\
\hline \multirow{6}{*}{$\begin{array}{l}\text { Semi-structured } \\
\text { interviews }\end{array}$} & OGTI official & 62 & 1 & & & & & & 1 \\
\hline & Local mental health officials & 101 & & & & & & 1 & 1 \\
\hline & Local statisticians & $43-100$ & & & 3 & & & 2 & 5 \\
\hline & PCC- $R$ case managers & $63-147$ & & & & $6^{\mathrm{a}}$ & $1^{b}$ & $5^{c}$ & 12 \\
\hline & PCC-R users & $21-58$ & & & 3 & 4 & 4 & 4 & 15 \\
\hline & Family members of users & $26-48$ & & & 1 & 3 & & 4 & 8 \\
\hline Total & & & 2 & 4 & 7 & 13 & 5 & 16 & 47 \\
\hline
\end{tabular}

DSAME, Mental Health Department; OGTI, General Information Technology Office; PCC-R, Continuity of Care and Rehabilitation Program; M, men; W, women.

a Six nurses.

One family doctor.

Four nurses and one occupational /physical therapist.

Source: Produced by authors, based on results. 
TABLE 2. Type and frequency of PCC-R activities based on level of severity of user's condition

\begin{tabular}{|c|c|c|c|}
\hline \multirow[t]{2}{*}{ Activities } & \multicolumn{3}{|c|}{ Level of severity } \\
\hline & High (red) & Medium (yellow) & Mild (green) \\
\hline Home visits for assessment, intervention, and monitoring & Daily or every two days & Weekly & Monthly \\
\hline Telephone calls as a part of monitoring & Every two days & Weekly & Monthly \\
\hline $\begin{array}{l}\text { Consultations or appointments for psychiatry, psychology, and } \\
\text { occupational therapy }\end{array}$ & Weekly & 2-3 times a month & Monthly \\
\hline $\begin{array}{l}\text { Psychoeducation on the mental disorder and medication, for users and } \\
\text { family members }\end{array}$ & 4 times in 3 months or less & & \\
\hline Craft or sports workshops, etc. & & & Weekly \\
\hline Visits to recreational areas to promote autonomy & & & Semiannual \\
\hline
\end{tabular}

Source: Produced by authors based on results.

manager, taking into account the manager's workload of the managers and the severity of the user's condition.

Preparation of ICCPs using a standardized form is a common task in the CSMCs. The plan describes the user's objectives in the PCC-R, the activities for achieving them, the responsible professionals, and the duration of the plan.

Although user participation is a basic premise, ICCPs are usually designed without it, partly because users are admitted to the PCC-R they tend to have difficulties in expressing their consent. Family members receive the explanation about the program and sign the consent, but they do not actively participate in the formulation of the ICCP.

The interviewed users stayed in the PCC-R more than six months, and although not all of them recognize the program by name, they do identify the different activities and say that they "support mental health," "provide care" and "improve." The family members do recognize the program and say that the user is continuously supported in their "rehabilitation" and "improvement."

The length of time users stay in the PCC-R is variable both within and across the CSMCs. One reason is that there are differences among the users such as their need for support or their resources, and specific targets are set for each individual. Another reason is that the CSMCs appear to have different views on the objective of the PCC-R, which are reflected in the length of time the users stay. In one CSMC in Lima the preset maximum stay was six months, which is reflected in an ICCP with better defined objectives, while in other CSMCs the stay was longer, with few medical discharges. This situation differs from what some managers learned during their training:

"The theory tells you that each color takes approximately a quarter of a year: one quarter in red, one quarter in yellow, one quarter in green (...) in other words, in theory, nine months in the PCC, right? No, not in real life... it might be one month, two months, one year, two years. One person has been in it since 2016, but that's because of the complexity of the case" (manager in Lima).

\section{Adoption and acceptability of the PCC-R}

The adoption of the PCC-R was reflected in the managers' usual intention to apply and implement the different activities of the PCC-R. Although there is variability from one CSMC to another, a significant number of common activities were identified, such as psychoeducation of users and family members and the intervention to improve daily life and recreational activities. These were carried out using typical methods such as home visits, phone calls, and follow-up meetings by the CSMC team.

Informants at both the local and central levels identified barriers to adopting PCC-R activities, largely related to financial and human resource management issues and program support. They also offered possible solutions (Table 3).

The managers reported broad acceptability of the PCC-R, a perception shared by decision makers. The managers said that it is a "necessary" and "important" program and working as part of a team yielded good outcomes. Positive aspects they mentioned included providing more support to users and being able to get to know them better. Finally, all of the managers were satisfied with the program's outcomes, although they did propose ways to improve it, such as standardizing its operation, increasing training opportunities, and increasing the CSMC team's commitment to implementing the activities.

"For me, this program is very important, very valuable; I feel better working as a team because working alone is impossible" (manager in Lima).

Users and family members also expressed broad acceptance of the PCC-R. The majority were "comfortable" or "satisfied" with care and the kind treatment they received from staff, including their "interest," "understanding," and "listening skills". The users said they were happy because they noticed physical, emotional, and social improvements, as reflected in reduced symptoms and greater integration in community and work environments.

\section{Monitoring of the PCC-R: current situation and recommendations}

The PCC-R still does not have any monitoring procedures, tools, or indicators. The CSMCs usually document their activities in the physical clinical history and in the HIS-MINSA reporting system. This system is limited to only recording activities (not results) and providing general information on the CSMC; it does allow PCC-R information to be filtered, which impedes proper monitoring. 
TABLE 3. Difficulties and suggestions for adoption of the PCC-R

\begin{tabular}{|c|c|c|}
\hline Area & Problems & Suggestions \\
\hline Management of financial resources & $\begin{array}{l}\text { Lack of funds for home visits and calls to users } \\
\text { Complicated, slow procedures for requesting and receiving funds }\end{array}$ & $\begin{array}{l}\text { Increase PCC-R budget } \\
\text { Include transportation for extramural activities in the PCC-R } \\
\text { technical policy } \\
\text { Establish partnerships with local institutions that provide support } \\
\text { (e.g., transportation) }\end{array}$ \\
\hline Human resources management & $\begin{array}{l}\text { Insufficient personnel } \\
\text { Overburdening PCC-R managers with CSMC or external tasks } \\
\text { (e.g., vaccination) }\end{array}$ & $\begin{array}{l}\text { Assign a full-time nurse to the PCC-R } \\
\text { Increase the number of professionals involved in the PCC-R }\end{array}$ \\
\hline Support for the PCC-R & $\begin{array}{l}\text { Health system officials prioritize the quantity of activities over } \\
\text { their quality: "the PCC-R has fewer activities than other services" } \\
\text { Rejection of the community model by some CSMC directors, } \\
\text { which impedes PCC-R activities such as field trips } \\
\text { Limited support of PCC-R activities by CSMC professionals, } \\
\text { since they consider them the responsibility of nurses }\end{array}$ & $\begin{array}{l}\text { Educate CSMC officials and teams about the community mental } \\
\text { health model } \\
\text { Include other CSMC professionals as managers in order to } \\
\text { engage them in the PCC-R } \\
\text { Include the performance of the PCC-R as a key indicator so that } \\
\text { becomes a priority }\end{array}$ \\
\hline
\end{tabular}

PPC-R, Continuity of Care and Rehabilitation Program; CSMC, community mental health center.

Source: Produced by authors based on results.

TABLE 4. Proposed indicators and topics to be explored in the assessment of PCC-R users

\begin{tabular}{|c|c|c|}
\hline \multicolumn{2}{|c|}{ Informant } & Description \\
\hline \multirow[t]{2}{*}{$\begin{array}{l}\text { Suggestions by local policy makers } \\
\text { and health professionals on } \\
\text { indicators }\end{array}$} & Descriptive and process indicators & $\begin{array}{l}\text { Description of PCC-R users } \\
\text { Number of PCC-R users, percentage of users with SMDs, percentage of users based on severity } \\
\text { of condition, percentage of users certified as being disabled, length of time in the PCC-R, } \\
\text { percentage of users that adhere to treatment, percentage of users that leave the PCC-R. } \\
\text { PCC-R activities } \\
\text { Number of PCC-R team meetings, number of home visits to users, number of phone calls to } \\
\text { users, number of completed ICCPS. }\end{array}$ \\
\hline & Quality and outcome indicators & $\begin{array}{l}\text { User satisfaction } \\
\text { Percentage of users satisfied with the PCC-R. } \\
\text { PCC-R successes } \\
\text { Number of users discharged, percentage of users with hospitalizations, relapses, or crises, } \\
\text { percentage of users reintegrated in work and community environments, percentage of users } \\
\text { whose symptoms improve; percentage of users whose quality of life, family wellbeing, and } \\
\text { social functionality improve. }\end{array}$ \\
\hline \multicolumn{2}{|c|}{$\begin{array}{l}\text { Suggestions of users and family members on topics to be explored in user } \\
\text { assessments }\end{array}$} & $\begin{array}{l}\text { Changes in symptoms and social conduct (in the family and at work) } \\
\text { Difficulties in understanding, adapting to, and adhering to treatment } \\
\text { Difficulties in resuming daily activities }\end{array}$ \\
\hline
\end{tabular}

PCC-R, Continuity of Care and Rehabilitation Program; SMDs, severe mental disorders; ICCP, individualized care continuity plan.

Source: Produced by authors based on results.

The managers said that their superiors in the Region rarely request reports on PCC-R activities, although they sometimes ask for specific data such as the number of users or home visits.

The managers use the clinical histories and their own records to monitor PCC-R users and compliance with the ICCP, which helps them evaluate and reformulate activities.

There is consensus on the need, usefulness, and viability of having a PCC-R monitoring system, which would help better reflect the activities of managers and improve the monitoring of users.

Furthermore, there is agreement on using the HIS-MINSA system to record the different data needed to monitor the PCC-R, because it is a "reliable," "well-known," and "userfriendly" system. The decisionmakers said that for this to happen, certain changes should be made in the HIS-MINSA system (e.g., to allow the filtering of PCC-R user data) and standardization of codes for purposes of reporting the program's activities.

Several decision makers at the central level expressed their willingness to also implement a complementary PCC-R reporting system that would make it possible to collect key data in short periods of time for monitoring purposes. The obstacle most frequently mentioned to adding this new system was the workload that it would entail for statisticians and managers.

The informants in the health system suggested the use of key indicators to evaluate the PCC-R (Table 4), which are categorized as descriptive and process indicators on PCC-R users and activities, and indicators on PCC-R quality and results.

Family members and users made recommendations for improving the evaluation they undergo in the PCC-R, which should also be considered in the design of the indicators (Table 4).

\section{DISCUSSION}

Our study describes the implementation of the PCC-R from the standpoint of its key participants, highlights the successes, difficulties, similarities, and differences in the program's operation, and gathers suggestions on how it could be improved. 
The PCC-R has become a key strategy of community mental health services in Peru and has broad acceptance among the people involved in it, with general satisfaction regarding its outcomes. However, there are also pending tasks that would improve the program's implementation and these are becoming increasingly necessary considering that the PCC-R will be operating in nearly 300 CSMCs in the next few years.

The study's findings are discussed below, and recommendations are made for four essential areas of the PCC-R: standardization, the execution of activities, training and support, and monitoring and evaluation.

\section{Standardization}

There is a need to develop a document that would describe the essential and common aspects of the PCC-R, from the program's objectives through its monitoring, that would facilitate its implementation, operation, and evaluation. The successful use of these policy documents would improve the quality of procedures and user care $(21,22)$. At the same time, it is important to ensure that the PCC-R can be adapted to accommodate different situations and users with different health conditions, needs, and resources $(23,24)$. The technical policy for the PCC-R is currently being developed and will draw on the results of this research study.

\section{Implementation of activities}

Although the PCC-R has broad acceptability, adopting it has posed various challenges ranging from an organizational culture that prioritizes quantity over quality to the overloading of case managers.

The first recommendation is to simplify the request, receipt, and spending of funds, and establish collaborative partnerships with local institutions that support the activities of the PCC-R. Evidence shows that the availability of resources to improve the operation and sustainability of a program must be ensured $(25,26)$. Second, there should be parameters for evaluating the productivity of the PCC-R, a program that is committed to the intensive and extended support of a limited number of users and therefore cannot be measured using the same criteria as other programs. Third, the assignment of fulltime PCC-R staff is required in order to improve the program's management and ensure the implementation of its activities and monitoring. Fourth, user participation must be encouraged, starting at the time they are admitted to the PCC-R. Finally, the identification and sharing of CSMC good practices is recommended.

\section{Training and support}

Ongoing training and support of staff are key aspects for successful implementation of a program, especially a recent one (25). Intensive trainings should be offered that provide essential content to all program staff. There should also be regular support opportunities and interprofessional education for managers and with outside experts, in order to answer questions, receive feedback, and devise joint solutions. As the literature shows, technological tools are useful for facilitating access to support and training $(27,28)$.

\section{Monitoring and evaluation}

Rigorous monitoring and evaluation are essential for not only ensuring the sustainability (26) but also the improvement (25) of health programs. The future PCC-R policy should include a monitoring system with process, quality, and outcome indicators, including relevant indicators for users and family members (29), and a reporting system that is technologically simple and undemanding to ensure its use by staff. These elements are key to effective health programs, since they ensure the timely collection of accurate information on their implementation and long-term impact (25).

It should be possible to set up the system quickly in order to monitor the PCC-R at the central, regional, and local levels. To this end, the recommendation is to improve the current HISMINSA system and add a simple reporting mechanism that facilitates the provision of the information used to estimate the indicators. These sources of information will be useful for evaluating the current state of the program so that periodic feedback can be given for evaluation and improvement purposes (25). Furthermore, external evaluations are recommended to determine the level of satisfaction of users and family members and consider their suggestions, which has been shown to improve the quality of care and the outcomes of the treatments received, by focusing on their needs $(30,31)$.

Finally, pilot studies on the new system should be conducted in order to refine the procedures and indicators before it is scaled up for all CSMCs in the country.

For reasons of time and available resources, the field work focused on four of the oldest CSMCs in Peru, which do not necessarily represent the situation in other newer CSMCs. Even so, since the first centers served as a model and in many cases were responsible for training the newer CSMCs, the existence of similar procedures and challenges is to be expected.

On the other hand, interviews with PCC-R users, sometimes due to their health situation and sometimes for desirability reasons, did not always yield much information, particularly criticisms or suggestions on the program. While it is necessary to keep working on methodologies that help mental health service users express their feelings and thoughts, the inclusion of family members also shed some light on the views of PCC-R users.

\section{CONCLUSIONS}

The PCC-R is a flagship program for the CSMCs and for the mental health reform in Peru and has achieved broad acceptability among providers and users. Its implementation combines successes and difficulties, with pending tasks that include developing a policy document, improving resource management, strengthening training and support, and implementing a monitoring system for informed decisionmaking and continuous improvement of the program.

Contribution of the authors. YC/FDC/MM/MT/VC/HC/ JC contributed to the conceptualization of the study and the procurement of funds. YC/FDC/MM were in charge of supervising activities. FDC/MT/VC/JRV handled the collection and analysis of data, preparation of drafts, review of documents, and editing. All of the authors reviewed and approved the final manuscript. 
Acknowledgements. The authors would like to thank the central officials of the Ministry of Health, local mental health officials, CSMC professionals, and users and family members for the information they provided. The authors also thank Jimena Rivas, Ana Lucía Vilela, and Jill Portocarrero for their support in the transcription of audio recordings and coding of interviews.

Conflict of interests. None declared by the authors.
Financial support. This research study was made possible by the financing of the Pan American Health Organization in the call for proposals "Embedding Research for the Sustainable Development Goals (ER-SDG)."

Declaration. Authors hold sole responsibility for the views expressed in the manuscript, which may not necessarily reflect the opinion or policy of the RPSP/PAJPH and/or PAHO.

\section{REFERENCES}

1. Instituto Nacional de Salud Mental "Honorio Delgado Hideyo Noguchi". Estudio epidemiológico de salud mental en Lima Metropolitana y Callao - Replicación 2012. Anales de Salud Mental. 2013;29. Available at: http://www.insm.gob.pe/investigacion/ archivos /estudios/2012 ASM -EESM -LM.pdf

2. World Health Organization. Mental Health Atlas 2011. Country profile: Peru. Geneva: WHO; 2011. Available at: https:/ / www.who.int/ mental_health/publications/mental_health_atlas_2011/en/\#: :text=Overview, $98 \% 25 \% 20$ of $\% 20$ the $\% 20$ world's $\% 20$ population.

3. Ministerio de Salud del Perú (MINSA). Carga de enfermedad en el Perú: estimación de los años de vida saludables perdidos 2016. Lima: MINSA; 2018. Available at: https://www.gob .pe/institucion/minsa/informes-publicaciones/276778-carga -de-enfermedad-en-el-peru-estimacion-de-los-anos-de-vida -saludables-perdidos-2016

4. Toyama M, Castillo H, Galea JT, Brandt LR, Mendoza M, Herrera V, et al. Peruvian mental health reform: a framework for scaling-up mental health sServices. Int J Heal Policy Manag. 2017;6(9):501-8.

5. Miranda JJ, Diez-Canseco F, Araya R, Cutipe Y, Castillo H, Herrera $\mathrm{V}$, et al. Transitioning mental health into primary care. The Lancet Psychiatry. 2017;4(2):90-2.

6. Government of Peru. Implementing regulations of Law N. ${ }^{\circ} 29.889$. SupremeDecreeN ${ }^{\circ}$ 033-2015-SA.Availableat:http://www.aprodeh .org.pe/documentos / marco-normativo/discapacidad /Reglamento_de_la_Ley_N_29889_Ley_que_modifica _el_articulo_11_de_la_Ley_26842_Ley_General_de_Salud_y _garantiza_los_derechos_de_las_personas_con_problemas_de _salud_mental.pdf

7. Ministerio de Economía y Finanzas del Perú. Programa presupuestal 0131: control y prevención en salud mental. Available at: https: / / www.mef.gob.pe/contenidos/presu_publ/ppr/prog presupuestal/articulados/0131_control_prevencion_salud_mental. pdf

8. Ministerio de Salud del Perú (MINSA). Plan nacional de fortalecimiento de servicios de salud mental comunitaria 2018-2021. Lima: MINSA; 2018.

9. Ministerio de Salud del Perú (MINSA). Norma técnica de salud: centros de salud mental comunitarios. Lima: MINSA; 2017.

10. Cubillos L, Muñoz J, Caballero J, Mendoza M, Pulido A, Carpio K, et al. Addressing severe mental illness rehabilitation in Colombia, Costa Rica, and Peru. Psychiatr Serv. 2020;71(4):378-84.

11. Dieterich M, Irving CB, Bergman H, Khokhar MA, Park B, Marshall $\mathrm{M}$. Intensive case management for severe mental illness. Cochrane Database Syst Rev. 2017;(1).

12. Adair CE, McDougall GM, Mitton CR, Joyce AS, Wild TC, Gordon A, et al. Continuity of care and health outcomes among persons with severe mental illness. Psychiatr Serv.2005;56(9):1061-9.

13. Pedraz A, Zarco J, Ramasco M, Palmar AM. Qualitative research. 1st ed. Barcelona: Elsevier; 2014.

14. Langlois E V, Mancuso A, Elias V, Reveiz L. Embedding implementation research to enhance health policy and systems: a multi-country analysis from ten settings in Latin America and the Caribbean. Heal Res Policy Syst. 2019;17(1):85.

15. Teddlie C, Yu F. Mixed methods sampling. J Mix Methods Res. 2007;1(1):77-100.
16. Bengtsson M. How to plan and perform a qualitative study using content analysis. NursingPlus Open. 2016;2:8-14.

17. Proctor E, Silmere H, Raghavan R, Hovmand P, Aarons G, Bunger A, et al. Outcomes for implementation research: conceptual distinctions, measurement challenges, and research agenda. Adm Policy Ment Heal. 2011;38(2):65-76.

18. Bachrach LL. Continuity of care and approaches to case management for long-term mentally ill patients. Psychiatr Serv. 1993;44(5): 465-8.

19. Bond GR, Drake RE, Mueser KT, Latimer E. Assertive community treatment for people with severe mental illness. Dis Manag Heal Outcomes. 2001;9(3):141-59.

20. Davini M, Nervi L, Roschke M. La capacitación del personal de los servicios de salud en proyectos relacionados con los procesos de reforma sectorial. Lima: Pan American Health Organization; 2002: 91. Available at: http://bvs.minsa.gob.pe/local/minsa/2780.pdf

21. Heymann T. Clinical protocols are key to quality health care delivery. Int J Health Care Qual Assur.1994;7(7):14-7.

22. Graham ID, Harrison MB. Evaluation and adaptation of clinical practice guidelines. Evid Based Nurs. 2005;8(3):68-72.

23. May CR, Johnson M, Finch T. Implementation, context and complexity. Implement Sci. 2016;11(1):141te.

24. Squires JE, Graham ID, Hutchinson AM, Michie S, Francis JJ, Sales $\mathrm{A}$, et al. Identifying the domains of context important to implementation science: a study protocol. Implement Sci. 2015;10 (1):135.

25. Frieden TR. Six components necessary for effective public health program implementation. Am J Public Health.2014;104(1):17-22.

26. Schell SF, Luke DA, Schooley MW, Elliott MB, Herbers SH, Mueller NB, et al. Public health program capacity for sustainability: a new framework. Implement Sci. 2013;8(1):15.

27. Evans S, Sonderlund A, Tooley G. Effectiveness of online interprofessional education in improving students' attitudes and knowledge associated with interprofessional practice. Focus Heal Prof Educ. 2013;14(2):12-20.

28. Islam MM, Parkinson A, Burns K, Woods M, Yen L. A training program for primary health care nurses on timely diagnosis and management of dementia in general practice: an evaluation study. Int J Nurs Stud. 2020;105:103550.

29. Kötter T, Schaefer F, Scherer M, Blozik E. Involving patients in quality indicator development: a systematic review. Patient Prefer Adherence. 2013;259-68.

30. Izadi A, Jahani Y, Rafiei S, Masoud A, Vali L. Evaluating health service quality: using importance performance analysis. Int J Health Care Qual Assur. 2017;30(7):656-63.

31. Reese RJ, Duncan BL, Kodet J, et al. Patient feedback as a quality improvement strategy in an acute care, inpatient unit: an investigation of outcome and readmission rates. Psychol Serv. 2018;15(4):470-6. Doi:10.1037/ser0000163

Manuscript (original in Spanish) received on 30 April 2020. Revised version accepted for publication on 14 September 2020. 


\section{Estudio cualitativo sobre la implementación del Programa de continuidad de cuidados y rehabilitación para personas con trastornos mentales graves en el Perú}

RESUMEN Objetivo. Describir la implementación del Programa de continuidad de cuidados y rehabilitación (PCC-R) en centros de salud mental comunitaria (CSMC) del Perú.

Métodos. Estudio cualitativo sobre la implementación del PCC-R en cuatro CSMC de Lima y La Libertad, Perú. Se realizaron 42 entrevistas semiestructuradas individuales y un grupo focal con cinco participantes, para un total de 47 informantes entre usuarios, familiares y profesionales vinculados al diseño, la implementación y el monitoreo del PCC-R.

Resultados. El PCC-R es un programa central de los servicios de salud mental comunitaria en Perú, goza de amplia aceptación y los prestadores y usuarios refieren estar satisfechos con sus resultados. Sin embargo, el programa carece de un documento normativo que detalle sus objetivos, organización y actividades, lo que explicaría la variabilidad en su aplicación. Existen limitaciones en la gestión de recursos financieros y humanos del PCC-R y necesidades de capacitación y supervisión, que deben ser mejoradas. Existe consenso sobre la necesidad, la utilidad y la viabilidad de desarrollar un sistema de monitoreo del PCC-R. Se recogen buenas prácticas y sugerencias para enfrentar estos retos.

Conclusiones. El PCC-R es un programa insignia de los CSMC y de la reforma de la salud mental en Perú, y ha logrado amplia aceptación entre los prestadores y usuarios. Su implementación combina aciertos y dificultades, y revela tareas pendientes como desarrollar un documento normativo, mejorar la gestión de recursos, fortalecer la capacitación y acompañamiento, y aplicar un sistema de monitoreo para favorecer la mejora continua del programa.

Palabras clave Continuidad de la atención al paciente; salud mental; centros comunitarios de salud mental; investigación cualitativa; Perú.

\section{Estudo qualitativo sobre a implementação do Programa de Continuidade de Cuidados e Rehabilitação para pessoas com transtornos mentais graves no Peru}

RESUMO

Palavras-chave
Objetivo. Descrever a implementação do Programa de Continuidade de Cuidados e Reabilitação (PCC-R) em centros de saúde mental comunitária (CSMCs) do Peru.

Métodos. Estudo qualitativo sobre a implementação do PCC-R em quatro CSMCs em Lima e La Libertad, no Peru. Realizamos 42 entrevistas semiestruturadas individuais e um grupo focal com cinco participantes, com um total de 47 participantes, entre usuários, familiares e profissionais envolvidos na elaboração, implementação e monitoramento do PCC-R.

Resultados. O PCC-R é um programa central dos serviços de saúde mental comunitária no Peru, conta com ampla aceitabilidade e os prestadores e usuários dizem estar satisfeitos com seus resultados. No entanto, o programa não possui um documento normativo que detalhe os seus objetivos, organização e atividades, o que pode explicar a variabilidade em sua aplicação. Existem limitações na gestão dos recursos financeiros e humanos do PCC-R e necessidades de capacitação e supervisão, que devem ser melhoradas. Há consenso sobre a necessidade, utilidade e viabilidade de se desenvolver um sistema de monitoramento do PCC-R.

Apresentamos aqui um conjunto de boas práticas e sugestões para enfrentar esses desafios.

Conclusões. O PCC-R é um programa emblemático dos CSMCs e da reforma da saúde mental no Peru, tendo obtido ampla aceitação entre prestadores e usuários. A sua implementação combina acertos e dificuldades e revela tarefas pendentes, tais como o desenvolvimento de um documento normativo, uma melhor gestão de recursos, o reforço da capacitação e supervisão e a aplicação de um sistema de monitoramento para fomentar a melhoria contínua do programa.

Continuidade da assistência ao paciente; saúde mental; centros comunitários de saúde mental; pesquisa qualitativa; Peru. 